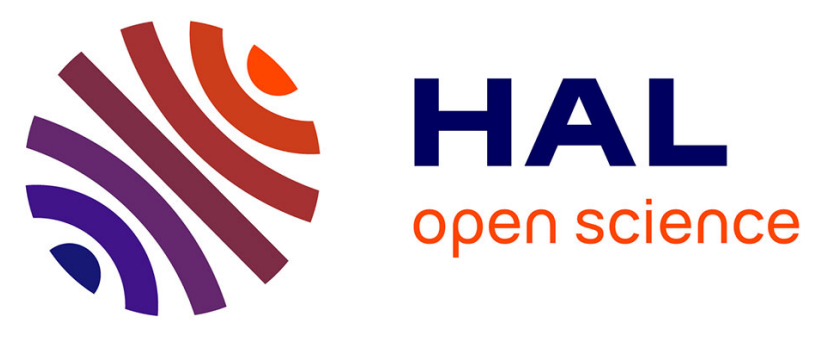

\title{
Visually undetected fever episodes in newly received beef bulls at a fattening operation: Occurrence, duration, and impact on performance
}

Edouard Timsit, Nathalie Bareille, Henri H. Seegers, Anne Lehébel, Sébastien Assie

\section{To cite this version:}

Edouard Timsit, Nathalie Bareille, Henri H. Seegers, Anne Lehébel, Sébastien Assie. Visually undetected fever episodes in newly received beef bulls at a fattening operation: Occurrence, duration, and impact on performance. Journal of Animal Science, 2011, 89 (12), pp.4272-4280. 10.2527/jas.20113892 . hal-02642659

\section{HAL Id: hal-02642659 \\ https://hal.inrae.fr/hal-02642659}

Submitted on 28 May 2020

HAL is a multi-disciplinary open access archive for the deposit and dissemination of scientific research documents, whether they are published or not. The documents may come from teaching and research institutions in France or abroad, or from public or private research centers.
L'archive ouverte pluridisciplinaire HAL, est destinée au dépôt et à la diffusion de documents scientifiques de niveau recherche, publiés ou non, émanant des établissements d'enseignement et de recherche français ou étrangers, des laboratoires publics ou privés. 


\title{
Visually undetected fever episodes in newly received beef bulls at a fattening operation: Occurrence, duration, and impact on performance $e^{1,2}$
}

\author{
E. Timsit, ${ }^{3}$ N. Bareille, H. Seegers, A. Lehebel, and S. Assié \\ LUNAM Université, ONIRIS, UMR 1300, Bio-aggression, Epidemiology and Risk Analysis, \\ and INRA, Nantes, F-44307, France
}

\begin{abstract}
Monitoring body temperature of newly received cattle allows for identification of fever episodes not visually detected by feedlot personnel (FENO). Information concerning the occurrence, duration, and impact on performance of these FENO is not available in the literature. Such information is crucial to assess the potential benefit of the identification and treatment of FENO. Therefore, the objectives of this study were to describe the occurrence and duration of FENO and to evaluate their impact on ADG. One hundred twelve beef bulls (initial BW $=346 \pm 36 \mathrm{~kg}$ ) were studied for $40 \mathrm{~d}$ after arrival at 3 French fattening operations. At d 1, each animal was administered orally a reticulo-rumen bolus, which allowed continuous measurement and recording of reticulo-rumen temperature. Animals were weighed on d 1 and 40. Bulls were observed twice daily by personnel for visual signs of apparent disease. Bulls that appeared ill, had a rectal temperature $\geq 39.7^{\circ} \mathrm{C}$, and demonstrated symptoms consistent with bovine respiratory disease $(\mathrm{BRD})$ were treated with antibiotics. After d 40, data obtained from the boluses were retrospectively analyzed using a cumulative sum test
\end{abstract}

to detect significant increases in reticulo-rumen temperature considered as fever episodes. Numerous fever episodes $(\mathrm{n}=449)$ were retrospectively detected in 110 bulls. Of these 449 fever episodes, $74 \%$ were not associated with any visually detected clinical signs of disease and thus were identified as FENO. These FENO were often transitory ( $75 \%$ lasted less than $47 \mathrm{~h}$ ). However, $25 \%$ lasted from 47 to $263 \mathrm{~h}$. Of the 112 bulls, 88 were treated for BRD with 20 and 7 animals treated, respectively, 2 and 3 times. In treated animals, fever episodes began 4 to $177 \mathrm{~h}($ mean $=50 \mathrm{~h})$ before BRD treatment. The duration of FENO was associated $(P=$ 0.002 ) with a lesser ADG (d 1 to 40$)$ : $-33 \mathrm{~g} / \mathrm{d}$ for daily FENO duration. Our results demonstrated that FENO occurred frequently in bulls during the first weeks after entrance into a fattening operation and can last up to 11 d. The impact of FENO observed on ADG in this study indicated a potential benefit of treating affected animals, specifically those with FENO of long duration. However, further research is needed to determine the medical and economic relevance of such treatment.

Key words: average daily gain, bovine respiratory disease, fever, reticulo-rumen temperature bolus

(C)2011 American Society of Animal Science. All rights reserved.

J. Anim. Sci. 2011. 89:4272-4280

doi:10.2527/jas.2011-3892

\section{INTRODUCTION}

Bovine respiratory disease (BRD), also referred to as shipping fever, continues to be one of the most economically significant health problems in cattle entering fattening operations (Duff and Galyean, 2007). Bovine respiratory disease is commonly observed throughout

\footnotetext{
${ }^{1}$ This study was supported by the French Ministry of Agriculture under project Monitoring Zootechnique des Animaux d'Élevage (MOZAE).

${ }^{2}$ The authors gratefully acknowledge R. Quiniou from INRA (Rennes, France) for his technical assistance and A. J. Roussel (Texas A\&M, College Station) for editorial assistance.

${ }^{3}$ Corresponding author: edouard.timsit@oniris-nantes.fr

Received January 20, 2011.

Accepted July 13, 2011.
}

the first weeks after arrival and accounts for 75 to $80 \%$ of overall illness cases during this period (Assié et al., 2009; Babcock et al., 2009).

Detection of BRD in fattening operations is not always accurate (Duff and Galyean, 2007). Indeed, current methods for identifying cattle with BRD often rely on observation of clinical illness performed by owners or feedlot staff, which have shown both low sensitivity $(62 \%)$ and low specificity $(63 \%)$ to identify BRD (White and Renter, 2009).

To improve BRD detection, new tools such as reticulo-rumen temperature boluses and infrared thermography scans were developed, which allow identification of changes in core body temperature associated with adverse health events (Schaefer et al., 2007; Timsit et al., 2011; Rose-Dye et al., 2011). In previous studies 
Table 1. Characteristics of 12 groups of bulls on their arrival in 3 fattening operations

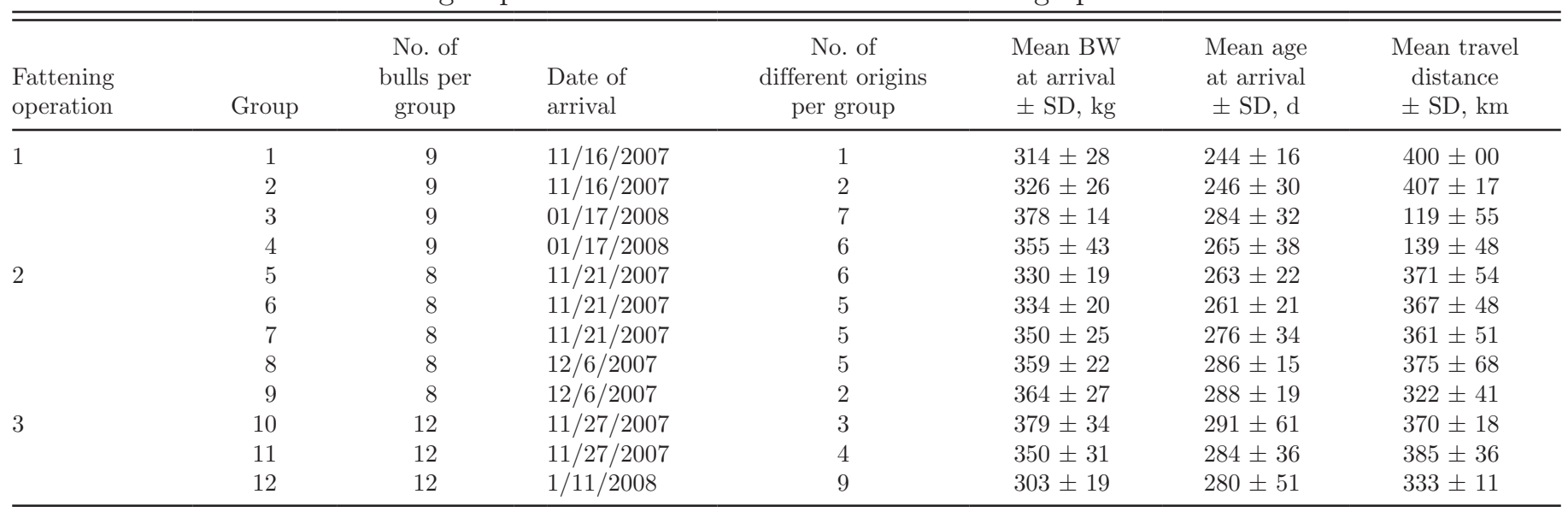

(Schaefer et al., 2007; Timsit et al., 2011), these tools enabled the early detection of fever episodes associated with apparent symptoms of BRD, such as labored breathing, coughing, decreased appetite, depression, nasal or ocular discharge. Furthermore, they also facilitated identification of fever episodes that were not visually detected by feedlot personnel (FENO). Limited information is available that describes the occurrence and duration of FENO and associated production consequences. Such information is nevertheless crucial to assess the potential benefit of the identification and treatment of FENO. Therefore, the objectives of this study were, first, to describe the occurrence and duration of FENO and, second, to evaluate their impact on the ADG of bulls in the feedlots. To facilitate identification of FENO, the bulls in this study were equipped with reticulo-rumen temperature boluses.

\section{MATERIALS AND METHODS}

All procedures in the present experiment were performed in accordance with the European directive (86/609) and the French regulation and conform to the Guide for the Care and Use of Laboratory Animals (US National Institutes of Health, 1996).

\section{Location and Timing}

This study was conducted on 3 commercial fattening operations in north-western France between November 2007 and March 2008. The operations were part of a cooperative. On these operations, weaned beef bulls entered the fattening operation at 7 to 10 mo of age and were slaughtered at 18 to 22 mo at a BW of approximately 700 to $750 \mathrm{~kg}$.

\section{Animals}

One hundred twelve Charolais $(\mathrm{n}=102)$ and Charolais $\times$ Limousin $(\mathrm{n}=10)$ bulls (initial $\mathrm{BW} \pm \mathrm{SD}$ $=346 \pm 36 \mathrm{~kg}$; initial age $\pm \mathrm{SD}=273 \pm 41 \mathrm{~d}$ ) were studied throughout the first $40 \mathrm{~d}$ after arrival at fat- tening operations (Table 1). Bulls that came from multiple origins were purchased at auction markets. After purchase, bulls were transported by truck over a mean distance of $329 \pm 104 \mathrm{~km}$ (range $=70$ to $515 \mathrm{~km}$ ) to a central facility where they were sorted into groups based on BW. Bulls were allowed free access to hay and water at the central facility for 36 to $48 \mathrm{~h}$. Then, bulls were transported by truck for travel distances less than $50 \mathrm{~km}$ to the 3 fattening operations. In total, 12 groups of 8 to 12 bulls were studied (Table 1 ).

After arrival at fattening operations, bulls were allowed to rest for at least $24 \mathrm{~h}$ with free access to hay and water before processing. This processing was done at $1500 \mathrm{~h}$ and consisted of individually weighing, deworming with $0.5 \mathrm{mg} \cdot \mathrm{kg}^{-1}$ of $\mathrm{BW}$ of eprinomectine pour-on (Ivomec, Merial, Villeurbane, France), and oral administration of a reticulo-rumen temperature bolus (Thermobolus, Medria SAS, Chateaugiron, France) using a typical plastic balling gun. None of the bulls received any vaccine or antibiotic during processing. Individual weighing was repeated at $1500 \mathrm{~h}$ at the end of the study period (d 40). Because BW varies depending on gut fill, the time of weighing was standardized in regard to time of feeding ( $6 \mathrm{~h}$ after the ration was provided).

During the fattening period, groups of bulls were kept in covered pens. Pens varied from 30 to $48 \mathrm{~m}^{2}$ including a lying area with straw bedding and an exercise area with a concrete floor, a water bowl, and a trough with 8 to 12 eating places. After arrival, bulls were initially fed grass-legume hay for ad libitum intake for $7 \mathrm{~d}$. Their ration was then gradually changed during wk 2 to 5 after arrival; the amounts of corn silage, concentrate (30\% CP, $10 \%$ crude fiber, $11 \%$ starch, $4.5 \%$ crude fat; DM basis), and straw were slowly increased to reach, respectively, 62,30 , and $8 \%$ of the ration, whereas the amount of hay was slowly decreased until none was given. This final ration was formulated to meet the French National Institute for Agriculture Research recommendations (Garcia et al., 2007). During the study period, the bulls were fed for ad libitum intake, and the quantity of feed provided each day was adjusted so that 
refusal corresponded to $10 \%$ of the amount distributed. Feed was mixed and delivered once daily at $0900 \mathrm{~h}$. Throughout the study period, animals had unlimited access to water. During the study period, the temperature inside the barns ranged from 2 to $19^{\circ} \mathrm{C}$.

\section{Reticulo-Rumen Temperature Bolus}

Reticulo-rumen temperatures were continuously recorded during the $40 \mathrm{~d}$ after entry of bulls at fattening operations by the use of commercial setups (Thermobolus, Medria SAS, Chateaugiron, France) as described previously (Timsit et al., 2011). Briefly, each setup consisted of a) a set of reticulo-rumen temperature boluses to be administered using a typical plastic balling gun (40 per fattening operation), b) a base station with an incorporated antenna placed $2 \mathrm{~m}$ high above the ground and approximately $15 \mathrm{~m}$ away from the pen of bulls, and c) a personal computer link to the base station by a RS32 cable.

To ensure the accuracy of the temperatures measured by the reticulo-rumen boluses, an in vitro test was performed before the ingestion of the boluses by the bulls as described previously (Timsit et al., 2011). Briefly, each bolus was immersed in a water bath and the temperatures measured by the boluses were compared with the reference measurement by a precision temperature measuring instrument (Pt100 \& P600, Dostmann Electronic GmbH, Wertheim-Reicholzheim, Germany) over the range of 20 to $45^{\circ} \mathrm{C}$.

\section{Clinical Assessment, Treatment, and Sampling Procedure}

Bulls were observed twice daily by feedlot personnel for the detection of signs of apparent disease. Animals showing 1 or more of the following signs were removed from the pen: depression, decreased rumen fill compared with penmates, nasal or ocular discharge, cough, and increased respiratory rate. Identified animals were walked to and restrained in a chute, a distance of less than $25 \mathrm{~m}$ from their pens. Then, they were physically examined by a veterinary practitioner to detect respiratory tract diseases or other diseases (e.g., lameness, digestive disorder, nervous disorder). All examined animals returned within $2 \mathrm{~h}$ to their pen.

Bulls with rectal temperature $\geq 39.7^{\circ} \mathrm{C}$ and exhibiting symptoms consistent with BRD (e.g., abnormal pulmonary sounds, coughing, polypnea/dyspnea, or nasal or ocular discharge) were treated (Galyean et al., 1999). These bulls received, via subcutaneous injection, $2 \mathrm{~mL}$ per $15 \mathrm{~kg}$ of $\mathrm{BW}$ of a product containing of 16.5 $\mathrm{mg} \cdot \mathrm{mL}^{-1}$ of flunixin meglumin and $300 \mathrm{mg} \cdot \mathrm{mL}^{-1}$ of florfenicol (Resflor, Intervet, Angers, France). If a clinical improvement was not observed by the fourth day, the same treatment was repeated.

Before BRD treatment, samples were taken from the lower respiratory tract using trans-tracheal aspiration (TTA) as described previously (Espinasse et al., 1991).
Trans-tracheal aspirations were performed before the first and second BRD treatment if the latter was separated from the first by more than $7 \mathrm{~d}$. On average, 5 to $10 \mathrm{~mL}$ of fluid was recovered. Tracheal aspirates were cooled, transported to the laboratory, and processed within $6 \mathrm{~h}$.

\section{Virology and Bacteriology}

Virus isolation from TTA aspirates was performed as described previously (Michel et al., 2010) using 2 passages in primary bovine fetal kidney cells. At the end of the second passage, cell cultures were stained by an immunoperoxidase procedure for the identification of bovine respiratory syncytial virus (BRSV), parainflenza 3 virus (Pi3), and bovine viral diarrhea virus (BVDV).

For Pasteurellaceae isolation, TTA aspirates were inoculated onto $5 \%$ sheep blood agar (Columbia, Oxoid, Hampshire, United Kingdom) and chocolate agar supplemented with PolyVitex (Biomerieux, Marcy l'Etoile, France). Sheep blood and chocolate agar plates were then incubated for $24 \mathrm{~h}$ at $37^{\circ} \mathrm{C}$ in, respectively, aerobic atmosphere and atmosphere of $5 \% \mathrm{CO}_{2}$. Afterward, colonies resembling Pasteurella multocida, Mannheimia haemolytica, or Histophilus somni were subcultured for another $24 \mathrm{~h}$ and identified by standard biochemical procedures (Quinn et al., 1994) and API (Biomerieux, Marcy l'Etoile, France).

Mycoplasma spp. was isolated as described previously (Arcangioli et al., 2008). Mycoplasma bovis were then identified by dot immunobinding on membrane filtration, using polyclonal hyperimmune rabbit antisera prepared against $M$. bovis, as described by Poumarat et al. (1991).

\section{Identification of Fever Episodes}

During the study period, neither the feedlot personnel nor the investigators had access to the reticulo-rumen temperatures measured by the boluses. Data obtained by the boluses were extracted from each on-farm computer at the end of the study period and retrospectively analyzed using a program provided by the manufacturer (Medria Measurement Manager, Medria SAS, Chateaugiron, France) as described previously (Timsit et al., 2011). Briefly, this program performed, first, the preprocessing of raw reticulo-rumen temperatures to eliminate water intake effects; second, the definition of a reference reticulo-rumen temperature for each bull (computed as the mean of all the preprocessed temperatures obtained during the previous $4 \mathrm{~d}$ ); and third, the detection of significant differences between preprocessed temperatures and reference temperatures [i.e., reticulo-rumen hyperthermia episodes using a method based on the cumulative sum (CUSUM) test (Hinkley, 1971; Page, 1954; Figure 1)]. The CUSUM parameters used in this study were $v$ (detector sensitivity) $=$ 0.65 and $\lambda$ (responsiveness) $=1.3$ (Timsit et al., 2011) . 


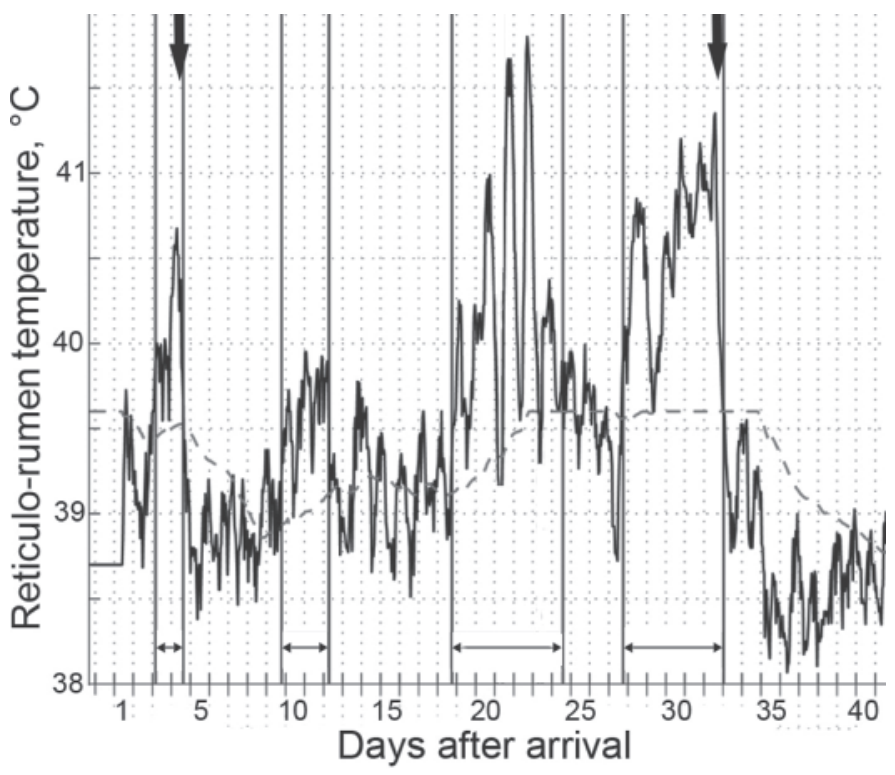

Figure 1. Example of reticulo-rumen temperatures (curve) for which water intake effects were eliminated (i.e., preprocessed reticulo-rumen temperature), measured in a beef bull during the first 40 $\mathrm{d}$ postarrival at a fattening operation. The reference reticulo-rumen temperature (dotted line), computed as the mean of preprocessed temperatures recorded during the previous $4 \mathrm{~d}$ is also shown. Four significant differences (horizontal arrow) between preprocessed temperatures and reference temperatures (i.e., reticulo-rumen hyperthermia episode) were identified using a method based on the cumulative sum test. Bovine respiratory disease treatments (vertical arrows) were implemented on d 4 and 32 after arrival.

Finally, to limit reticulo-rumen hyperthermia episode splits, often due to bad preprocessing of close water drinking events, reticulo-rumen hyperthermia episodes separated by less than $6 \mathrm{~h}$ were merged into a single episode.

Reticulo-rumen hyperthermia episodes identified by the CUSUM test were considered as fever episodes in the present study. Indeed, increased rectal temperatures (mean $\pm \mathrm{SD}=40.1 \pm 0.6^{\circ} \mathrm{C}$ ) were systematically observed during reticulo-rumen hyperthermia episodes identified by the same CUSUM test in a previous study (Timsit et al., 2011). Furthermore, reticulo-rumen temperature is correlated to rectal temperature as described previously by Rose-Dye et al. (2011; $\mathrm{r}=0.89 ; \mathrm{n}$ $=264)$, Timsit et al. (2011; $\mathrm{r}=0.91 ; \mathrm{n}=135)$, Bewley et al. (2008; $\mathrm{r}=0.64 ; \mathrm{n}=2042)$, and Sievers et al. $(2004 ; \mathrm{r}=0.92 ; \mathrm{n}=36)$.

\section{Data Analysis}

Fever Episodes and Visually Apparent Clinical Signs of Disease. The results of fever episode identification were correlated with health data obtained during the study period. Fever episodes during which apparent signs of BRD or other diseases that were detected by feedlot personnel were defined as FECS, whereas fever episodes not visually detected by feedlot personnel were defined as FENO. The characteristics of FECS and FENO, including duration and mean reticulo-rumen temperatures recorded during fever episodes, were described and then compared using a Student test (SAS Inst. Inc., Cary, NC). The total number and duration of FECS and FENO per bull during the study period were calculated as well as time lags between the onsets of FECS and BRD treatments and time lags between BRD treatments and the ends of FECS.

Effect of $\boldsymbol{F E N O}$ on $\boldsymbol{A D G}$. Early ADG was calculated from BW measured on $\mathrm{d} 1$ during the processing and BW measured at the end of the study period (d 40). The effect on early ADG of FENO was assessed using a mixed linear regression model (PROC MIXED, SAS). Individual bull was the experimental unit. Variables including number of BRD treatments, breed, BW at entry, age at entry, total duration of FECS during the study period, and total duration of FENO during the study period were tested for their association with early ADG in univariate analysis. Only variables that were associated with early ADG at $P<0.20$ in the univariate analysis were included to a multivariate model. Because of the collinearity between total duration of FECS and number of BRD treatments, only number of BRD treatments was included in the model. After checking for the linearity of the effect, total duration of FENO was considered as a continuous variable. Model selection was based on backward elimination of candidate variables. For each evaluation of the model, the variable with the largest Fisher's test $P$-value was removed. This process was repeated until all remaining variables were significantly associated with the early ADG $(P<0.05)$. The final mixed model was written as follows:

$$
\mathrm{Y}_{i j k l}=\alpha+\mathrm{FENO}_{i}+\mathrm{TT}_{j}+\mathrm{BR}_{k}+\mathrm{PEN}_{l}+\varepsilon_{i j k l}
$$

where outcome $\mathrm{Y}$ is the early $\mathrm{ADG}, \alpha$ is the intercept, FENO is the total duration of FENO during the study period expressed in days (quantitative), TT is the number of BRD treatments performed during the study period (4 classes), BR is the breed (2 classes), PEN is the pen of the bull nested within fattening unit (12 classes, random effect), and $\varepsilon$ is the residual. Results are discussed as significant if $P \leq 0.05$.

\section{RESULTS}

\section{Detection of Fever Episodes}

Before ingestion by the bulls, all the reticulo-rumen temperature boluses showed an overall accuracy in vitro of $\pm 0.2^{\circ} \mathrm{C}$ over the range of 20 to $45^{\circ} \mathrm{C}$ (data not shown). The boluses were easily administered at arrival, and no regurgitation or loss in feces was observed throughout the study period.

Of the 112 bulls, 110 had from 1 to 11 fever episodes during the $40 \mathrm{~d}$ after their arrival at the fattening operations (Table 2). The daily prevalence of bulls with fever episodes, relative to the time of arrival at the fattening operations, is indicated in Figure 2. In total, 449 fever episodes having lasted from 5 to $263 \mathrm{~h}$ (mean $=$ 
Table 2. Descriptive statistics of fever episodes identified in 110 bulls equipped with reticulo-rumen temperature boluses during the first $40 \mathrm{~d}$ postarrival at fattening operations

\begin{tabular}{|c|c|c|c|c|c|c|}
\hline Item & Mean (SD) & Minimum & $\mathrm{Q} 1^{1}$ & Median & $\mathrm{Q}^{1}$ & Maximum \\
\hline Duration of fever episodes, $\mathrm{h}$ & $44(40)$ & 4 & 17 & 32 & 56 & 263 \\
\hline Time lag between successive fever episodes, $\mathrm{h}$ & $110(125)$ & 6 & 17 & 53 & 175 & 614 \\
\hline Mean reticulo-rumen temperatures recorded during fever episodes, ${ }^{\circ} \mathrm{C}$ & $40.3(0.3)$ & 39.8 & 40.1 & 40.2 & 40.5 & 41.9 \\
\hline
\end{tabular}

$44 \pm 40 \mathrm{~h}$ ) were retrospectively indentified by the CUSUM test. During fever episodes, mean reticulo-rumen temperatures averaged $40.3^{\circ} \mathrm{C}$, ranging from 39.8 to $41.9^{\circ} \mathrm{C}$. The time lag between successive fever episodes in the same animal ranged from 6 to $614 \mathrm{~h}$. Over the 40 $\mathrm{d}$, the total duration of fever episodes per bull varied from 7 to $528 \mathrm{~h}($ mean $=181 \pm 112 \mathrm{~h})$.

\section{Health Data}

No clinical signs related to diseases other than BRD (e.g., lameness, neurological signs) were observed throughout the study period. Of the 112 bulls entering the study, 88 (79\%) were treated for BRD (Table 3). Descriptive statistics, including mean number of days on feed and mean rectal temperature at the time of each treatment, are shown in Table 3. Sixty-one animals were treated once, 20 were treated twice, and 7 were treated 3 times for BRD. In total, 122 treatments were performed during the study period. The daily prevalence of $\mathrm{BRD}$ treatment, relative to the time of arrival at the fattening operation, is indicated in Figure 2. No mortality was observed.

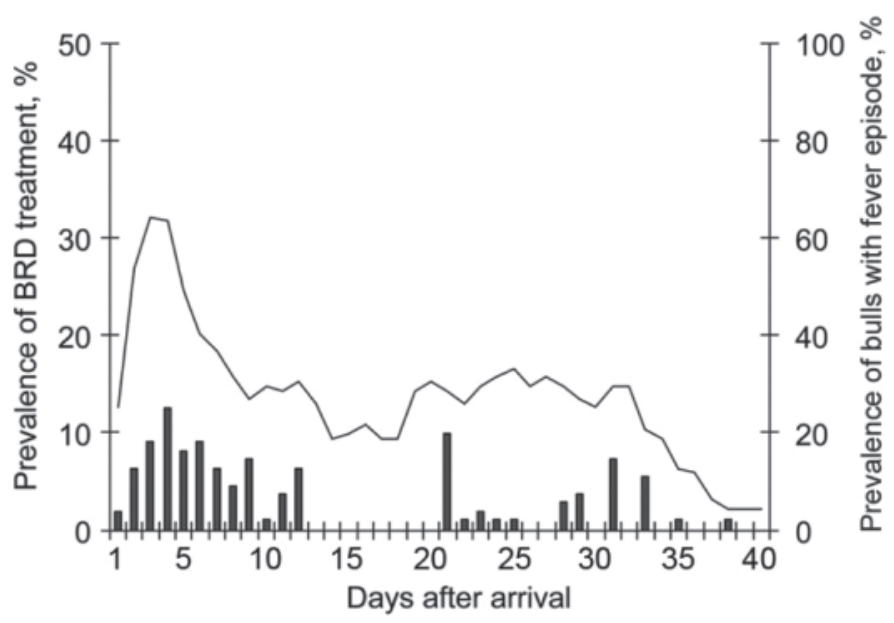

Figure 2. Daily prevalence (\%) of bovine respiratory disease (BRD) treatment (histogram; number of BRD treatments per d/112 $\times 100)$ and daily prevalence (\%) of bulls with fever episode (curve; number of bulls that had fever episode on indicated day $/ 112 \times 100)$ in 112 bulls equipped with reticulo-rumen temperature boluses.

\section{Bacteriological and Virological Results}

Before BRD treatment, 103 TTA were performed (Table 3). Pasteurellaceae (Mannheimia haemolytica and Pasteurella mutocida), and viruses (BRSV, Pi3, and BVDV), M. bovis, or both were isolated from 96 of 103 TTA aspirates (93\%). Frequencies of bacterial and viral isolations are shown in Table 3. No Histophilus somni was isolated from TTA aspirates, and no cytopathogenic effect characteristic of Bovine herpes virustype 1 was observed on cell cultures.

\section{Fever Episodes and Visually Apparent Clinical Signs}

Of the 449 fever episodes, $74 \%$ were not associated with any visually apparent clinical signs of BRD or signs of other disease detected by feedlot personnel (Table 4). These FENO were, on average, shorter ( $P$ $<0.001$ ) than FECS (mean $=40$ vs. $56 \mathrm{~h}$; Table 4 ). Indeed, FENO were often transitory with $75 \%$ having lasted less than $47 \mathrm{~h}$. However, it should be noticed that $25 \%$ of FENO lasted from 47 to $263 \mathrm{~h}$. Contrary to duration, mean reticulo-rumen temperatures recorded during fever episodes did not differ between FECS and FENO $(P=0.51)$. During the study period, bulls had FECS and FENO during, on average, 75 and $134 \mathrm{~h}$, respectively (Table 5). The time lag between FECS onset and BRD treatment averaged $50 \mathrm{~h}$, ranging from 4 to $177 \mathrm{~h}$ (Table 6). This time lag was calculated for 116 of the $122 \mathrm{BRD}$ treatments because of water drinking, which artificially ended reticulo-rumen hyperthermia episodes within 4 to $6 \mathrm{~h}$ before 6 treatment implementations. After BRD treatment, FECS systematically ended within 1 to $18 \mathrm{~h}$ (mean $=5 \pm 3 \mathrm{~h})$.

\section{Effect of FENO on Early ADG}

Mean early ADG of bulls was 1,159 $\pm 469 \mathrm{~g}$. Table 7 shows that the total duration of FENO during the study period was associated $(P=0.002)$ with a lesser ADG: $-33 \mathrm{~g} / \mathrm{d}$ for daily FENO duration. The occurrence of BRD treatment was also associated with a lesser ADG: $-139 \mathrm{~g}(P=0.040),-316 \mathrm{~g}(P=0.015)$, and $-655 \mathrm{~g}(P<0.001)$ when, 1,2 , or 3 treatments were administered in the same animal. 
Table 3. Descriptive statistics of health data and pathogens isolated from trans-tracheal aspiration (TTA) aspirates before the implementation of bovine respiratory disease (BRD) treatment in 88 bulls during the first $40 \mathrm{~d}$ postarrival at fattening operations

\begin{tabular}{|c|c|c|c|}
\hline \multirow[b]{2}{*}{ Item $^{1}$} & \multicolumn{3}{|c|}{ BRD treatment ${ }^{2}$} \\
\hline & First & Second & Third \\
\hline No. of treatments & 88 & 27 & 7 \\
\hline \multicolumn{4}{|l|}{ DOF, d } \\
\hline Mean (SD) & $6.9(7.2)$ & $22.7(8)$ & $31.0(6)$ \\
\hline Range & 0 to 31 & 5 to 33 & 22 to 39 \\
\hline \multicolumn{4}{|l|}{ Temp, ${ }^{\circ} \mathrm{C}$} \\
\hline Mean (SD) & $40.4(0.4)$ & $40.2(0.3)$ & $40.4(0.5)$ \\
\hline No. of TTA ${ }^{3}$ & 88 & 15 & 0 \\
\hline Negative viral and bacterial growth & 6 & 1 & - \\
\hline Virus positive & 43 & 8 & - \\
\hline Bovine respiratory syncytial virus & 10 & 7 & - \\
\hline Parainflenza 3 virus & 32 & 3 & - \\
\hline Bovine viral diarrhea virus & 5 & 4 & - \\
\hline Pasteurellaceae positive & 63 & 9 & - \\
\hline Mannheimia haemolytica & 46 & 8 & - \\
\hline Pasteurella multocida & 18 & 1 & - \\
\hline Mycoplasma bovis positive & 15 & 11 & - \\
\hline
\end{tabular}

\section{DISCUSSION}

The existence of undetected (i.e., visual assessment) fever episodes (i.e., FENO) in cattle managed in fattening systems have been reported (Hoerlein and Marsh, 1957). However, to the knowledge of the authors, this is the first time that the occurrence and duration of FENO were quantified by the use of a telemetric device, which allowed continuous and noninvasive monitoring of core body temperature. The use of reticulo-rumen temperature boluses allowed the retrospective identification by a CUSUM test of numerous FENO $(\mathrm{n}=333)$ in 110 bulls during the first weeks after their arrival at fattening operations. Among FENO, a large number were only transitory ( $75 \%$ lasted less than $47 \mathrm{~h}$ ). However, $25 \%$ lasted up to $11 \mathrm{~d}$. Furthermore, this study provides unique information on the impact of FENO on ADG of bulls managed in a fattening system. The duration of FENO was associated with a lesser ADG between d 1 and $40(-33 \mathrm{~g} / \mathrm{d}$ for daily FENO duration) resulting in a loss in BW at d 40 of $1.3 \mathrm{~kg}$ for daily FENO duration.

Because reticulo-rumen temperature is influenced by ruminal fermentation (Dale et al., 1954), feeding may lead to an increase of the reticulo-rumen temperature in the absence of an increase in core body temperature. However, the reticulo-rumen hyperthermia episodes identified by the CUSUM test, considered as fever episodes in the present study, were highly unlikely to be

Table 4. Characteristics of fever episodes for which apparent signs of bovine respiratory disease were visually detected by feedlot personnel (FECS) and for which no visually apparent clinical signs of disease were detected by feedlot personnel (FENO) in 110 bulls equipped with reticulo-rumen temperature boluses

\begin{tabular}{lcc}
\hline \hline Item $^{1}$ & FECS & FENO \\
\hline No. (\%) of fever episodes ${ }^{2}$ & $116(26 \%)$ & $333(74 \%)$ \\
Duration of fever episodes, h & $56^{\mathrm{a}}(39)$ & $40^{\mathrm{b}}(40)$ \\
Mean (SD) & $48(27$ to 72$)$ & $25(15$ to 47$)$ \\
Median (Q1 to Q3) & 5 to 182 & 6 to 263 \\
Range & $40.4^{\mathrm{a}}(0.36)$ & $40.3^{\mathrm{a}}(0.31)$ \\
Mean reticulo-rumen recorded during fever episodes, ${ }^{\circ} \mathrm{C}$ & 40.3 & 40.2 \\
Mean (SD) & 39.8 to 41.4 & 39.9 to 41.9 \\
Median (Q1 to Q3) & \\
Range & & \\
\hline${ }^{\mathrm{a}, \mathrm{b}}$ Means within a row with different superscripts are different $(P<0.05)$. & \\
${ }^{1}$ Q1 $=25$ th percentile; Q3 $=75$ th percentile. & \\
${ }^{2}$ Fever episodes were retrospectively identified by the use of a cumulative sum test applied on reticulo-rumen \\
temperatures recorded during the first 40 d postarrival at fattening operations.
\end{tabular}


Table 5. Occurrence and total duration of fever episodes for which apparent signs of bovine respiratory disease were detected by feedlot personnel (FECS) and for which no visually apparent clinical signs of disease were detected by feedlot personnel (FENO) in 112 bulls equipped with reticulo-rumen temperature boluses during the first $40 \mathrm{~d}$ postarrival at fattening operations

\begin{tabular}{|c|c|c|c|c|c|c|}
\hline Item & Mean (SD) & Minimum & $\mathrm{Q} 1^{1}$ & Median & $\mathrm{Q} 3^{1}$ & Maximum \\
\hline \multicolumn{7}{|l|}{ FECS $^{2}$ per bull } \\
\hline No. of FECS & $1(1)$ & 0 & 1 & 1 & 2 & 3 \\
\hline Total duration of FECS, $\mathrm{h}$ & $75(56)$ & 0 & 31 & 61 & 99 & 276 \\
\hline \multicolumn{7}{|l|}{$\mathrm{FENO}^{2}$ per bull } \\
\hline No. of FENO & $3(2)$ & 0 & 2 & 3 & 4 & 8 \\
\hline Total duration of FENO, $\mathrm{h}$ & $134(86)$ & 0 & 65 & 123 & 179 & 380 \\
\hline
\end{tabular}

due to feeding. Indeed, the reticulo-rumen temperature does not usually exceed $39.6^{\circ} \mathrm{C}$ in healthy bulls (Timsit et al., 2011), and in the present study, temperatures measured by the boluses during reticulo-rumen hyperthermia episodes averaged $40.1^{\circ} \mathrm{C}$. Furthermore, we have shown in a previous study (Timsit et al., 2011) that high rectal temperatures (mean $\pm \mathrm{SD}=40.1 \pm$ $0.6^{\circ} \mathrm{C}$ ) were systematically observed during reticulorumen hyperthermia episodes identified by the same CUSUM test.

In the present study, the treatment rate for BRD $(79 \%)$ is in the upper range of the treatment rates typically reported in French fattening operations (Assié et al., 2009). This increased rate could be explained, first, by the selection of high-BRD-risk bulls. Bulls were purchased at auction markets from multiple sources and transported by truck. These 2 factors are recognized as major risk factors for BRD (Taylor et al., 2010). Second, this increased rate could be explained by an improved detection of BRD by the feedlot personnel who knew that a study was being conducted and by the frequent visits of a veterinary practitioner. Because this study was conducted in high-BRD-risk bulls, a question would remain regarding possible differences in the occurrence, duration, and impact on performance of FENO in low-BRD-risk cattle.

The large number of FENO of short duration observed in the present study could be explained by infections that were overcome by the immune system of the bulls before the onset of clinical signs. Indeed, exposure of bulls to major BRD pathogens such as Mannheimia haemolytica even when combined with BVDV does not necessarily lead to visually apparent clinical signs but could result in a transitory FENO (Burciaga-Robles et al., 2010; Hanzlicek et al., 2010). This explanation has been previously proposed by Hoerlein and Marsh (1957) after they observed a large number of transitory fever episodes $(<2$ d) which appeared without other signs of disease in Hereford steer calves during the first $10 \mathrm{~d}$ after shipping. However, some transitory increases of core body temperature detected in this study could also be nonpyrogenic hyperthermias. In fact, the social behavior of the bulls, particularly agonistic interactions (e.g., fighting, butting, and threatening) and mounting, which are frequent during the first 2 wk after mixing (Mounier et al., 2005), could generate internal heat load leading to hyperthermia, which can last for a few hours. Therefore, the role of the interaction of the bulls in the contribution of core body temperature increases lasting less than $1 \mathrm{~d}$ cannot be excluded.

The FENO of long duration observed in this study could be explained by BRD cases, which occur without obvious clinical signs detectable by visual appraisal, and thereby may also be called subclinical BRD. Indeed, due to the prey/predator behavior, morbid animals often mask any signs of vulnerability (e.g., depression, illness), especially if they perceive the personnel handling them as predators (Weary et al., 2009). In previous studies having compared lung lesions at slaughter and BRD treatments implemented during the finishing

Table 6. Time lags between onsets of fever episodes and bovine respiratory disease (BRD) treatments, and between BRD treatments and ends of fever episodes in 88 bulls equipped with reticulo-rumen temperature boluses, which were treated for BRD during the first $40 \mathrm{~d}$ postarrival at fattening operations

\begin{tabular}{|c|c|c|c|c|c|c|}
\hline Time lags, h & Mean (SD) & Minimum & $\mathrm{Q} 1^{1}$ & Median & $\mathrm{Q} 3^{1}$ & Maximum \\
\hline Between BRD treatments and ends of fever episodes & $5(3)$ & 1 & 3 & 4 & 6 & 18 \\
\hline
\end{tabular}

\footnotetext{
${ }^{1} \mathrm{Q} 1=25$ th percentile; $\mathrm{Q} 3=75$ th percentile.

${ }^{2}$ Fever episodes were retrospectively identified by the use of a cumulative sum test applied on reticulo-rumen temperatures recorded during the first $40 \mathrm{~d}$ postarrival at fattening operations.

${ }^{3}$ Time lags were calculated for $116 \mathrm{BRD}$ treatments.
} 
Table 7. Final regression model for effects on early ADG (calculated from d 1 to 40) of fever episodes not associated with visually apparent clinical signs (FENO) of disease, number of bovine respiratory disease (BRD) treatments during the study period, and breed in 112 bulls equipped with reticulo-rumen temperature boluses

\begin{tabular}{lcccc}
\hline \hline & & \multicolumn{2}{c}{$95 \%$ confidence interval } & \\
\cline { 3 - 4 } Independent variable $_{\text {and level }}^{1}$ & Estimate $^{2}$ & Lower bound & Upper bound & $P$-value \\
\hline Duration of FENO per d $^{3}$ & -33 & -53 & -13 & 0.002 \\
No. of BRD treatments $^{4}$ & Reference & - & - & - \\
1 & -139 & -239 & -39 & 0.040 \\
2 & -316 & -516 & -116 & 0.015 \\
3 & -655 & -985 & -325 & $<0.001$ \\
Breed $^{5}$ & & & - & - \\
Charolais $_{\text {Charolais crossbreed }}$ & Reference & - & -89 & $<0.001$ \\
\hline
\end{tabular}

${ }^{1}$ Pen nested within fattening operation (random effect); $P=0.040$.

${ }^{2}$ Intercept $=1,539(1,324 ; 1,753) ; P<0.001$.

${ }^{3} \mathrm{FENO}$ were retrospectively identified by the use of a cumulative sum.

${ }^{4}$ Sixty-one, 20, and 7 bulls were treated, respectively, once, twice, and 3 times during the $40 \mathrm{~d}$ postarrival at fattening operations.

${ }^{5}$ One hundred two Charolais and 10 Charolais $\times$ Limousin bulls were studied during the $40 \mathrm{~d}$ postarrival at fattening operations.

period (Wittum et al., 1996; Thompson et al., 2006; Schneider et al., 2009), up to $68 \%$ of steers that were not visually detected or treated for BRD had lung lesions indicative of BRD. Furthermore, in a previous study (Timsit et al., 2011) where bulls with fever episodes were systematically examined every 12 to $24 \mathrm{~h}$ until the end of fever, we have shown that abnormal pulmonary sounds at lung auscultation were present during $81 \%$ of the fever episodes identified using the same CUSUM test, whereas an obvious BRD sign, such as depression, was only observed during $38 \%$ of these fever episodes. However, because bulls with FENO were not clinically examined by a veterinary practitioner in the present study, it is not possible to ensure that all FENO of long duration were caused by subclinical BRD.

The association found in the present study between duration of FENO and lesser ADG could first be explained by a reduced feed intake, which is frequent during prolonged fever (McMillan, 1985). In a previous study, Sowell et al. (1998) found, using an electronic feed monitoring system, that healthy feedlot steers spent $30 \%$ more time at the feed bunk than morbid steers. Second, this association could be explained by an increased catabolism and metabolic rate during fever, leading to a reduced feed conversion ratio (Loew, 1974). Unfortunately, because individual DMI was not measured in this study, it is not possible to differentiate these 2 causes.

The association between duration of FENO and lesser ADG indicates a potential benefit of treating FENO, especially the FENO of long duration. Indeed, a treatment with an antipyretic agent could alleviate anorexia associated with fever and relieve animal discomfort (McMillan, 1985). Furthermore, the use of an antimicrobial drug could treat the primary disease in the case of bacterial infection. Nevertheless, further re- search is needed before recommending such antimicrobial treatment. Indeed, the involvement of bacteria in the pathogenesis of FENO needs to be investigated. In the absence of bacterial involvement, such antimicrobial treatment may lead to unnecessary antimicrobial use, which could promote the emergence of bacterial resistance.

In conclusion, the results of this study point out that FENO occurs frequently in bulls during the first weeks after entrance into a fattening operation and can last up to $11 \mathrm{~d}$. The impact of FENO observed on ADG in this study indicates a potential benefit of treating affected animals, specifically those with FENO of long duration. However, further research is needed to determine the medical and economic relevance of such treatment.

\section{LITERATURE CITED}

Arcangioli, M. A., A. Duet, G. Meyer, A. Dernburg, P. Bézille, F. Poumarat, and D. Le Grand. 2008. The role of Mycoplasma bovis in bovine respiratory disease outbreaks in veal calf feedlots. Vet. J. 177:89-93.

Assié, S., H. Seegers, B. Makoschey, L. Desire-Bousquie, and N. Bareille. 2009. Exposure to pathogens and incidence of respiratory disease in young bulls on their arrival at fattening operations in France. Vet. Rec. 165:195-199.

Babcock, A. H., B. J. White, S. S. Dritz, D. U. Thomson, and D. G. Renter. 2009. Feedlot health and performance effects associated with the timing of respiratory disease treatment. J. Anim. Sci. $87: 314-327$.

Bewley, J. M., M. E. Einstein, M. W. Grott, and M. M. Schutz. 2008. Comparison of reticular and rectal core body temperatures in lactating dairy cows. J. Dairy Sci. 91:4661-4672.

Burciaga-Robles, L. O., D. L. Step, C. R. Krehbiel, B. P. Holland, C. J. Richards, M. A. Montelongo, A. W. Confer, and R. W. Fulton. 2010. Effects of exposure to calves persistently infected with bovine viral diarrhea virus type $1 \mathrm{~b}$ and subsequent infection with Mannheima haemolytica on clinical signs and immune 
variables: Model for bovine respiratory disease via viral and bacterial interaction. J. Anim. Sci. 88:2166-2178.

Dale, H. E., R. E. Stewart, and S. Brody. 1954. Rumen temperature. I. Temperature gradients during feeding and fasting. Cornell Vet. $44: 368-374$.

Duff, G. C., and M. L. Galyean. 2007. BOARD-INVITED REVIEW: Recent advances in management of highly stressed, newly received feedlot cattle. J. Anim. Sci. 85:823-840.

Espinasse, J., J. P. Alzieu, C. Papageorgiou, J. C. Beguin, and F. Van Gool. 1991. Use of transtracheal aspiration to identify pathogens in pneumonic calves. Vet. Rec. 129:339.

Galyean, M. L., L. J. Perino, and G. C. Duff. 1999. Interaction of cattle health/immunity and nutrition. J. Anim. Sci. 77:11201134 .

Garcia, F., J. Agabriel, and D. Micol. 2007. Alimentation des bovins en croissance et à l'engrais. Pages 89-120 in Feeding of Cattle, Sheep and Goats: Animals' Requirements and Feed Value. INRA Quae Editions, Versailles, France.

Hanzlicek, G. A., B. J. White, D. Mosier, D. G. Renter, and D. E. Anderson. 2010. Serial evaluation of physiologic, pathological, and behavioral changes related to disease progression of experimentally induced Mannheimia haemolytica pneumonia in postweaned calves. Am. J. Vet. Res. 71:359-369.

Hinkley, D. V. 1971. Inference about the change-point from cumulative sum test. Biometrika 58:509-523.

Hoerlein, A. B., and C. L. Marsh. 1957. Studies on the epizootiology of shipping fever in calves. J. Am. Vet. Med. Assoc. 131:123-127.

Loew, F. M. 1974. A theoretical effect of fever on feed efficiency in livestock. Can. Vet. J. 15:298-299.

McMillan, F. D. 1985. Fever: Pathophysiology and rational therapy. Compend. Contin. Educ. Pract. Vet. 7:845-855.

Michel, E., C. Quefelec, S. Serrand, M. Jamelot, and E. Le Drean. 2010. Improvement of the methods of virological diagnosis on cellular culture. Rev. Méd. Vét. (Toulouse) 161:157-161.

Mounier, L., I. Veissier, and A. Boissy. 2005. Behavior, physiology, and performance of bulls mixed at the onset of finishing to form uniform body weight groups. J. Anim. Sci. 83:1696-1704.

Page, E. S. 1954. Continuous inspection schemes. Biometrika 41:100-115.

Poumarat, F., B. Perrin, and D. Longchambon. 1991. Identification of ruminant mycoplasmas by dot immunobinding on membrane filtration ( $\mathrm{mf}$ dot). Vet. Microbiol. 29:329-338.

Quinn, P. J., M. E. Carter, B. K. Markey, and G. R. Carter. 1994. Pasteurella species. Pages 254-259 in Clinical Veterinary Microbiology. P. J. Quinn, M. E. Carter, B. K. Markey, and G. R. Carter, ed. Mosby, Edinburgh, UK.

Rose-Dye, T. K., L. O. Burciaga-Robles, C. R. Krehbiel, D. L. Step, R.W. Fulton, A.W. Confer, and C. J. Richards. 2011. Rumen temperature change monitored with remote rumen temperature boluses following challenges with bovine viral diarrhea virus and Mannheimia haemolytica. J. Anim. Sci. 89:1193-1200. doi:10.2527/jas.2010-3051.

Schaefer, A. L., N. J. Cook, J. S. Church, J. Basarab, B. Perry, C. Miller, and A. K. Tong. 2007. The use of infrared thermography as an early indicator of bovine respiratory disease complex in calves. Res. Vet. Sci. 83:376-384.

Schneider, M. J., R. G. Tait Jr., W. D. Busby, and J. M. Reecy. 2009. An evaluation of bovine respiratory disease complex in feedlot cattle: Impact on performance and carcass traits using treatment records and lung lesion scores. J. Anim. Sci. $87: 1821-1827$.

Sievers, A. K., N. B. Kristensen, H. J. Laue, and S. Wolffram. 2004. Development of an intraruminal device for data sampling and transmission. J. Anim. Feed Sci. 13:207-210.

Sowell, B. F., J. G. Bowman, M. E. Branine, and M. E. Hubbert. 1998. Radio frequency technology to measure feeding behavior and health of feedlot steers. Appl. Anim. Behav. Sci. 59:277284.

Taylor, J. D., R. W. Fulton, T. W. Lehenbauer, D. L. Step, and A. W. Confer. 2010. The epidemiology of bovine respiratory disease: What is the evidence for predisposing factors? Can. Vet. J. 51:1095-1102.

Thompson, P. N., A. Stone, and W. A. Schultheiss. 2006. Use of treatment records and lung lesion scoring to estimate the effect of respiratory disease on growth during early and late finishing periods in South African feedlot cattle. J. Anim. Sci. 84:488-498

Timsit, E., S. Assie, R. Quiniou, H. Seegers, and N. Bareille. 2011. Early detection of bovine respiratory disease in young bulls using reticulo-rumen temperature boluses. Vet. J. 190:136-142. doi:10.1016/j.tvjl.2010.09.012

US National Institutes of Health. 1996. Guide for the Care and Use of Laboratory Animals. Publ. No 85-23. US National Institutes of Health, ed. Natl. Acad. Press, Washington, DC.

Weary, D. M., J. M. Huzzey, and M. A. von Keyserlingk. 2009. BOARD-INVITED REVIEW: Using behavior to predict and identify ill health in animals. J. Anim. Sci. 87:770-777.

White, B. J., and D. G. Renter. 2009. Bayesian estimation of the performance of using clinical observations and harvest lung lesions for diagnosing bovine respiratory disease in post-weaned beef calves. J. Vet. Diagn. Invest. 21:446-453.

Wittum, T. E., N. E. Woollen, L. J. Perino, and E. T. Littledike. 1996. Relationships among treatment for respiratory tract disease, pulmonary lesions evident at slaughter, and rate of weight gain in feedlot cattle. J. Am. Vet. Med. Assoc. 209:814-818. 